Akinola, Olanrewaju Olugbenga Ph.D \& Heuva, William Ph.D

${ }^{1}$ Mass Communication Department, Olabisi Onabanjo University, Ago-Iwoye, Nigeria

${ }^{2}$ Communication Department, North West University, Mafikeng Campus, South Africa

Corresponding Authors' e-mail: akinola.lanre@oouagoiwoye.edu.ng william.heuva@nwu.ac.za

\title{
Democracy and Political Marketing in Nigeria: 2015, The Critical Turning Point
}

\begin{abstract}
Nigeria's current democratic dispensation which started in 1999 entered its sixteenth year with the general elections held between March 28 and April 11, 2015. This study takes a retrospective look at Nigeria's democratic journey since independence, with particular emphasis on the 2015 Presidential elections won by the opposition All Progressive Congress' (APC) candidate, General Mohammadu Buhari. The processes leading to the 2015 general elections; its results and reactions to the results and the electoral process are reviewed from the political marketing perspective. Survey, observation and review of relevant literature formed the body of data for the study. The study submits that market-oriented strategy is starting to evolve in Nigeria and also that the country has reached a critical juncture in her democratic journey and she cannot afford to slide back.
\end{abstract}

Key words: Political marketing strategies, Advertising, Branding, Integrated Marketing Communication (IMC), Social Media.

\section{Introduction}

Political Marketing is an exciting new area of study. It has arrested the attention of politicians, academics, journalists and the public in developed democracies. Scholars and theorists in the field of political marketing posit that the introduction of marketing strategies and tools to democracy has made elections and governance to be more voter-centric. They reason that the practice of political marketing is geared towards the understanding and development of policies/products that meet the needs and wants of the electorate and by extension, assisting the political parties and candidates to attain their set objectives (see Lees-Marshment, 2001a, b; Ormrod, 2007).

While some acknowledge its contributions to politics (democracy and governance), some others treat political marketing with suspicion and trepidation. Strömbäck \& Nord (2005) argue that simply adopting market-oriented strategies will not necessarily lead to election victory in all countries and party systems: That in some systems, it may actually lead to an electoral backlash. Kohli \& Jaworski (1990), also note from the commercial market point of view, that the implementation of market orientation does not automatically result in an increased performance. That in some circumstances, a product or sales orientation would be more profitable to the firm depending on the nature of the competitive environment.

With the 2015 presidential election in Nigeria producing for the first time, a complete change of government from Peoples' Democratic Party (PDP) to All Progressives Congress (APC), can the success of Muhammadu Buhari of APC and the failure of Goodluck Jonathan of PDP be attributed to the adoption or nonadoption of the principles and practices of political marketing? Ascertaining the marketing strategies the two leading political parties (APC \& PDP) and their campaign teams and consultants subscribed to and adopted in their bid to win the 2015 presidential election was the main objective of this study. Determining the effectiveness of the political marketing strategies used, identifying the critical turning points and predicting the direction and future of political marketing in Nigeria were the other set objectives of this study. 


\section{Background to Nigeria's Democracy}

The amalgamation of the Northern and Southern Protectorates by the British colonial government in 1914 tactically signified the birth of the nation called Nigeria. After 100 years of this relationship, a number of people across ethnic, demographic, professional and political lines are still of the opinion that the marriage was unholy. Nigeria, Africa's most populated country is made up of 250 ethnic groups, with Hausa/Fulani, Ibo and Yoruba being the dominant. It is the interaction of the politics of these three major ethnic groups and their combined efforts to drive out their British ruler that constitute the story of Nigerian politics (Olusanya, 1973:1).

When Nigeria attained independence on 1st October 1960, its citizens and the international community hoped that with abundant human and natural resources the country is endowed with, the new country will make steady and sustained progress towards the attainment of peace, democracy and development. It however, did not take long before these dreams were dashed (Omotola, 2005; Akinwunmi, 2004; Osaghae, 1998).The failure of the First Republic and the transition from hope to despair became manifest when the immediate post-independent Nigerian politicians failed to fundamentally address the crises and contradictions that emanated from the arrangement handed down to them by the departing colonial masters Singh (2011). The divide and rule policies of the British colonial government, Oyovbaire (1989) noted, divided the country along regional and ethnic lines and made regionalism an inherent part of the psyche of the Nigerian state.

The deepening of these contradictions did not only lead to the collapse of the First Republic, it brought about the first military coup of 15th January 1966 (Dudley, 1982; Adekanye, 1981), and laid the foundation for the 1967 civil war which lasted for 30 months. Between the period 1966 to 1979, Nigeria witnessed series of coups and counter-coups. Within these 13 years, the nation had four military Heads of State. In between this period, the nation fought a 30-month civil war (1967-1970). Generals Yakubu Gowon, Muritala Mohammed and Olusegun Obasanjo, respectively managed the nation as Heads of State during the civil war and post-civil war years.

The Second Republic which started in October 1979 also came to an abrupt end in December 1983 when the military struck and took over government. The Buhari/Idiagbon military regime was itself overthrown through a counter-coup in 1985 by General Badamosi Babangida. It is on record that Babangida's regime organized and midwifed the longest and most expensive transition to democracy. The transition took seven years (1986-1993) and cost the nation over N40 billion (Ojo, 2000; Diamond, Kirk-Green \& Oyadiran, 1996). Though the electoral process of the transition was adjudged to be of good standard, the election of June 12, 1993 considered the freest and fairest in the nation's history and presumed to have been won by the late business mogul, M.K.O. Abiola was annulled and the transition truncated by the military led government of General Badamosi Babangida.

In 1998, when General Abdulsalam became the Head of State after the mysterious and sudden death of General Sani Abacha (who ruled Nigeria between 1994 and 1998), he (Abdulsalam) midwifed the shortest transition programme in the history of the country (10 months). It is that transition process that heralded the current democratic dispensation. By implication, of the 55 years of Nigeria's independence, the military held sway for 30 years, while the civilian had only ruled the nation for 25 years. But for the 1993 general elections which were eventually annulled by the military-led government of General Ibrahim Babangida, elections in Nigeria have always been a-do-or-die-affair. Conduct of elections in Nigeria's evolving democracy is deficient in cardinal ingredients (Aluaigba, 2008), progressively declining (Alemika \& Omotosho, 2008) and inconsistent with the term and spirit of democracy (Ojo, 2000). While political campaigns and elections in other parts of the world center on ideology and issues, there seems to be a convergence of opinion among political power brokers and seekers in Nigeria, that political power can only be attained through electoral fraud and violence. Indeed, 'democracy and Nigeria are like Siamese twins; though conjoined, they are uncomfortable and under intense pressure that could result in all forms of hurt, even death' (Ajayi \& Ojo, 2014:107).

Democracy, either as a concept or a system of rule, has become excessively ambiguous in contemporary political analysis. Indeed, there is probably no concept that has been so subjected to varying definitions, antagonistic interpretations and contradictory practises as the concept of democracy (Ajayi \& Ojo, 2014:107). However, democracy is largely interpreted to mean 'rule by the people'. Abraham Lincoln in an address delivered at the dedication of the Soldiers' National Cemetery on 19 November 1863 in Gettysburg, Pennsylvania, gave what has since become the most famous definition of democracy. He defined democracy as 'government of the people, by the people, for the people'. This definition makes the people the subject and object of democracy. Holding regular elections is globally accepted as the hallmark of democracy. The processes and activities that lead to leadership succession and regime change constitute the major parameter upon which democracy is assessed.

\section{The Driving Theories}

Downs' (1957) Rational Choice Model and Lees-Marshment's (2001) Comprehensive Political Marketing (CPM) Model drive this study. The models are used to highlight the critical turning points in the 2015 presidential election. In brief, the rational choice model posits that an individual voter calculates the expected benefits and the cost of voting to decide whether to vote or not to vote. When he perceives that the cost of voting outweighs the expected benefit, or that his singular vote for a particular party or candidate will not 
change the result, he may rationally consider voting a wasted venture. However, the model has been expanded to cover group and society. Hence, an individual who ordinarily does not see any personal benefit in voting for a party or candidate, may be motivated to vote because it is compulsory (in some societies), it is a civic responsibility or a societal or group norm.

Comprehensive Political Marketing (CPM) model is the result of a research conducted into the behaviour of the British Labour Party as it transited from "productoriented" approach in 1983, through to a "salesorientation" in 1987, and finally achieving a "marketorientation" and electoral success in 1997. In 1983, the Labour Party was product-oriented in its approach to the election. The party argued for what it stood for and believed in. It assumed that the voters will see its position as right and then vote for it. The party was not ready and willing to change its ideas or product even if it fails to gain electoral or membership support. The behaviour of the Labour Party in 1983, according to Lees-Marshment (2001) closely resembled a product-orientation, because the programme the party offered was not in consonance with the concerns of majority of the voters.

In 1987, Labour Party stocked to its predetermined product design, but recognizing that the voters may not want it, rather than change the product design, it used market intelligence to understand voters' response to its behaviour, and employed the latest advertising and communication technologies to persuade voters that its offering is good and right. A sales-oriented party does not change its behaviour to suit what people want, rather it tries to make people want what it has to offer. As it happened in 1983, the party failed to win the election. A market-oriented party designs its behaviour to provide voter satisfaction. It uses market intelligence to identify voter demands and then design its products to suit them. A market-oriented party does not attempt to change what people think, but to deliver what they need and want. This, Lees-Marshment observed was exactly what the Labour Party did in 1997 under the leadership of Tony Blair. She recalls that the party went through a longer and more complex marketing process of full scale market intelligence to know the needs and wants of the voters, thereafter, designed and adjusted the products to meet voters' needs. The design was implemented and communicated before and during the election. At the end, the Labour Party won the election and its membership rose.

\section{Methodology}

Data for this study was collected through survey of electorate, the researcher's observation of 2015 general elections, and secondary data sourced from published academic works, public documents, Newspapers and online resources. The study was cross-sectional in respect of the study population and time of investigation; hence, the researchers had a one-time contact with the selected population after the 2015 presidential election.
The survey population consist of members of the voting public (electorate) who registered and voted in the 2015 presidential election. They were selected to ascertain the relevance and effectiveness of the political marketing strategies adopted by the two leading political parties/candidates in the 2015 presidential electoral contest. Taking into cognisance that there are 67,422,005 registered voters and 29 registered political parties (INEC, 2015) scattered across 36 States and the Federal Capital Territory Abuja, a compact area of 923,768sq. km. (Nationmaster, 2013), and the limited resources available for this study, the study was restricted to the six South Western States. In all, 1,348 respondents were purposively selected and surveyed. This number is based on the number of registered voters per state on the ratio of 1 - 10,003 approximate. (Please see the break-down in the table 1 below)

\section{Table 1. Showing allocation of questionnaire per state}

\begin{tabular}{|c|l|l|l|c|}
\hline No & States & Registered voters & Capital City & $\begin{array}{l}\text { No of } \\
\text { Questionnaire }\end{array}$ \\
\hline 1 & Lagos & $5,827,846$ & Ikeja & 583 \\
\hline 2 & Ogun & $1,709,409$ & Abeokuta & 171 \\
\hline 3 & Ekiti & 723,255 & Ado-Ekiti & 72 \\
\hline 4 & Ondo & $1,501,549$ & Akure & 150 \\
\hline 5 & Osun & $1,378,113$ & Osogbo & 138 \\
\hline 6 & Oyo & $2,344,448$ & Ibadan & 234 \\
\hline & Total & $\mathbf{1 3 , 4 8 4 , 6 2 0}$ & & $\mathbf{1 , 3 4 8}$ \\
\hline
\end{tabular}

The survey instrument (questionnaire) consists of twenty seven (27) questionnaire items. Seven (7) of these focused on demographic information while the remaining Twenty (20) consist of questions relating to voters' voting experiences, their perception of the political parties and their candidates and the voters' decision making process. The researchers' observation of the processes leading to the 2015 Presidential elections; its results and reactions to the results and secondary data sourced from published academic works, public documents, Newspapers and online resources were also reviewed and analysed.

The quantitative data collected were coded in line with the research objectives and then entered into a computer and analysed using Statistical Package for Social Scientists (SPSS) programme. The percentage number of respondents according to variables such as; sex, age, political party affiliation, electorate's perception of political party/candidates campaign strategies, factors that influenced voters' voting decision etc. were then computed and presented using frequency distribution tables. This, and the researchers' observations and review of secondary data informed conclusions of this study.

\section{Before the 2015 Elections}

The stake was obviously high: PDP prided itself as the biggest political party in Africa and planned to rule Nigeria for at least 60 years. Four opposition political parties, Action Congress of Nigeria (ACN), Congress for 